\title{
Biogenic coal-to-methane conversion efficiency decreases after repeated organic amendment stimulation
}

\section{Authors: Katherine J. Davis, Elliott P. Barnhart, Matthew W. Fields, and Robin Gerlach}

This document is the unedited author's version of a Submitted Work that was subsequently accepted for publication in Energy \& Fuels, copyright (c) American Chemical Society after peer review. To access the final edited and published work, see https://doi.org/10.1021/ acs.energyfuels. $7 \mathrm{~b} 03426$.

Davis, Katherine J., Elliott P. Barnhart, Matthew W. Fields, and Robin Gerlach. "Biogenic Coal-toMethane Conversion Efficiency Decreases after Repeated Organic Amendment." Energy \& Fuels 32, no. 3 (January 30, 2018): 2916-2925. doi:10.1021/acs.energyfuels.7b03426. 


\title{
Biogenic Coal-to-Methane Conversion Efficiency Decreases after Repeated Organic Amendment
}

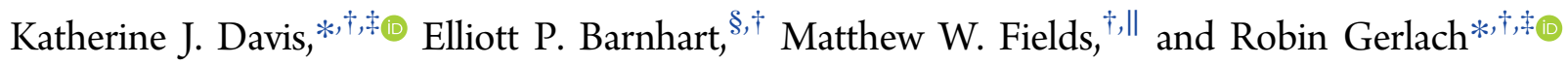 \\ ${ }^{\dagger}$ Center for Biofilm Engineering, Montana State University, Bozeman, Montana 59717, United States \\ ${ }^{\ddagger}$ Department of Chemical and Biological Engineering, Montana State University, Bozeman, Montana 59717, United States \\ ${ }^{\S}$ U.S. Geological Survey, Helena, Montana 59601, United States \\ "Department of Microbiology and Immunology, Montana State University, Bozeman, Montana 59717, United States
}

Supporting Information

\begin{abstract}
Addition of organic amendments to coal-containing systems can increase the rate and extent of biogenic methane production for 60-80 days before production slows or stops. Understanding the effect of repeated amendment additions on the rate and extent of enhanced coal-dependent methane production is important if biological coal-to-methane conversion is to be enhanced on a commercial scale. Microalgal biomass was added at a concentration of $0.1 \mathrm{~g} / \mathrm{L}$ to microcosms with and without coal on days 0,76 , and 117 . Rates of methane production were enhanced after the initial amendment but coal-containing treatments produced successively decreasing amounts of methane with each amendment. During the first amendment period, $113 \%$ of carbon added as amendment was recovered as methane, whereas in the second and third amendment periods, $39 \%$ and $32 \%$ of carbon added as amendment was recovered as methane, respectively. Additionally, algae-amended coal treatments produced $\sim 38 \%$ more methane than unamended coal treatments and $\sim 180 \%$ more methane than amended coal-free treatments after one amendment. However, a second amendment addition resulted in only an $\sim 25 \%$ increase in methane production for coal versus noncoal treatments and a third amendment addition resulted in similar methane production in both coal and noncoal treatments. Successive amendment additions appeared to result in a shift from coal-to-methane conversion to amendment-tomethane conversion. The reported results indicate that a better understanding is needed of the potential impacts and efficiencies of repeated stimulation for enhanced coal-to-methane conversion.
\end{abstract}

\section{INTRODUCTION}

Natural gas found in many of the world's coal reserves is commonly referred to as coalbed methane (CBM). It can be formed by thermogenic or biogenic processes and is commercially produced in some regions. Unlike thermogenic $\mathrm{CBM}$, formed by heat and pressure on geologic time scales, biogenic CBM is formed by microbial processes that convert coal to methane and occur on shorter time scales, thus providing an opportunity for enhancement strategies for increased production. ${ }^{1-4}$

The Powder River Basin (PRB) in Montana and Wyoming is the largest known U.S. coal reserve and a site of commercial CBM collection. Previous studies have shown that the methane collected in the PRB is almost exclusively of biogenic origin. ${ }^{5-7}$ Commercial collection of biogenic CBM often exceeds the rate of microbial methane production; therefore most production wells have short lifespans (7-10 years). ${ }^{8,9}$ When wells no longer produce commercially viable gas quantities to justify continued pumping, wells are often abandoned, leaving coal and valuable infrastructure in place. In the Montana portion of the PRB alone, there were 1046 shut-in or abandoned wells and an additional 597 with expired permits in 2015. Thus, the PRB is potentially a lucrative environment for application of strategies to increase the rates and amounts of microbially produced methane utilizing the already in place infrastructure for collection.
Previous studies have tested methods for enhancing biogenic coal-to-methane conversion in the laboratory, demonstrating enhanced biogenic methane production from coal using a variety of inorganic and organic nutrient additions ${ }^{7,10,11}$ and coal oxidation pretreatments. ${ }^{12-15}$ However, most of these methods could be too costly to implement in situ due to the investment required for production, transport, and application of the amendment. The use of yeast extract or tryptic soy broth, which are commonly used nutrients for the cultivation of diverse microorganisms, have been implemented as methaneenhancing amendment strategies to reduce the necessity of determining the exact "recipe" of nutrients needed, making it a potentially less expensive addition. ${ }^{4,16-18}$ However, the application of even the lowest-cost commercial-grade yeast extract $(\$ 8.50 / \mathrm{kg})$ to in situ coalbeds could be prohibitively expensive compared to use in ex situ bioreactors, and lessexpensive alternatives need to be investigated. ${ }^{16,19,20}$

In an effort to address potential costs associated with enhanced CBM production by amendment addition, the use of algal extract as an alternative amendment for increasing microbial coal-to-methane conversion has been introduced. ${ }^{18}$ Microalgae can grow in CBM production water ponds, and a Neospongiococcum spp. isolated from a production water pond 
has been shown to accumulate lipids. ${ }^{21}$ In addition to lipids for potential biofuel production, microalgae have also been grown commercially for production of nutritional supplements, food additives, fertilizer, aquaculture feedstock, and other high-value chemicals. ${ }^{22}$ Potential amendment transportation costs could be reduced by growing algae on or near the CBM collection site, while providing alternative economic benefits in the form of biofuels or other value-added products. ${ }^{16,18}$ Thus, the costs associated with CBM enhancement could be reduced by using microalgal amendments. The methane enhancement effect of organic amendments (microalgae, cyanobacteria, and yeast cells and extract) was investigated at two concentrations and demonstrated similar methane production with all amendments. $^{17}$

Most CBM enhancement studies have been performed using batch systems, and it has been observed that methane production rates and amounts can be increased for a period up to 80 days before methane production slows down or ceases completely in nearly all studies. ${ }^{11,14,17,23,24}$ The purpose of this study was to determine whether methane production can be increased repeatedly when systems are reamended after enhanced methane production has slowed down. The studies presented here focus on microalgal amendment at a low amendment concentration $(0.1 \mathrm{~g} / \mathrm{L})$ which was shown to better maintain the coal-to-methane converting microbial community structure compared to higher amendment concentrations. ${ }^{17}$

For a long-term application of enhanced CBM strategies in situ, it is necessary to ascertain the potential benefits and challenges arising from repeated amendments of coal systems and the potential economic impacts on methane enhancement strategies. The results of this study build on previous work ${ }^{17}$ and contribute toward a better understanding of the ability of complex organic amendments to increase microbial production of coalbed methane with repeated amendment addition.

\section{MATERIALS AND METHODS}

2.1. Site and Sample Collection. The sampling site, located near Birney, Montana, in the PRB, was thoroughly described previously. ${ }^{25}$ Water from the Flowers-Goodale (FG) coal bed was pumped and retrieved in May 2016 from the FGP-13 well. Two well volumes were pumped prior to formation water collection. Plastic jugs (6-gal volume) were rinsed twice with formation water before being filled and stored at $4{ }^{\circ} \mathrm{C}$ prior to microcosm set up. Formation water characterization for the FG coal bed has been previously reported. ${ }^{25}$ Coal cores were collected during the July 2013 drilling of the FG monitoring wells (FGM-13 and FGP-13). Twelve-inch sections of the 2 -in. diameter cores were placed in polyvinyl chloride (PVC) tubes that were filled completely with formation water from the FG-11 well and sealed with flexible rubber caps. Microbes were collected from FGM-13 in September 2015 using microbial samplers similar to those previously described. ${ }^{26}$ Liquid from the FGM-13 sampler was added to 3 serum bottles prepared with $5 \mathrm{~g}$ of FG coal and $45 \mathrm{~mL}$ of anoxic FG formation water before being incubated at room temperature $(21 \pm 1$ ${ }^{\circ} \mathrm{C}$ ) in the dark. The three serum bottles were combined prior to use as inoculum for the described studies.

2.2. Amendment Growth and Preparation. A Chlorella microalga species, strain SLA-04, was grown in photobioreactors for biomass accumulation as previously described. ${ }^{17}$ The biomass was lyophilized and stored at $-20{ }^{\circ} \mathrm{C}$ before being used in microcosm studies. The algal amendment was ground to a fine powder with a ceramic mortar and pestle. A $1 \mathrm{~g} / \mathrm{L}$ stock solution (dry w/v) was prepared in $0.2 \mu \mathrm{m}$ filtered and degassed FG formation water and sealed in oxygen-free serum bottles using anoxic methods.

2.3. Microcosm Setup and Reamendment. Microcosms were set up anoxically in $26 \mathrm{~mL}$ Balch tubes with butyl rubber stoppers and aluminum crimp seals. The FG coal core (depth $374-376$ feet $[\sim 114$ $\mathrm{m}]$ ) was opened in an anaerobic glovebag, and the core material was dried, crushed, and sieved to an effective size range $(0.85-2.0 \mathrm{~mm})$. The prepared coal was stored in oxygen-free glass bottles until microcosms were established. Borosilicate glass beads $(1 \mathrm{~mm})$ were autoclaved and used in lieu of coal to provide a carbon-free solid substrate as appropriate controls. Each Balch tube received $1 \mathrm{~g}$ of prepared coal or glass beads (GB). The formation water was filtered with $0.2 \mu \mathrm{m}$ bottle top filters and sparged for $5 \mathrm{~h}$ with an oxygen-free gas mixture $\left(5 \% \mathrm{CO}_{2} / 95 \% \mathrm{~N}_{2}\right)$. Sodium sulfide $\left(1 \mathrm{mM}\right.$ as $\mathrm{Na}_{2} \mathrm{~S}$. $9 \mathrm{H}_{2} \mathrm{O}$ ) was used as an oxygen scavenger to ensure low redox conditions. All amended treatments received $1 \mathrm{~mL}$ of the prepared amendment concentrate. The initial $\mathrm{pH}$ of the degassed and reduced formation water was 7.6, similar to what has been observed in the FG formation water. ${ }^{25}$ All inoculated treatments received $1 \mathrm{~mL}$ of inoculum from the combined serum bottles of the previously enriched FG microbial consortium. The initial total liquid volume of all microcosms was $10 \mathrm{~mL}$. Inoculum slurry was frozen and lyophilized for carbon analysis $(5 \mathrm{~mL})$. All microcosms were incubated in the dark at room temperature $\left(21 \pm 1{ }^{\circ} \mathrm{C}\right)$, approximately $3{ }^{\circ} \mathrm{C}$ warmer than the in situ $\left(\sim 18{ }^{\circ} \mathrm{C}\right)$ temperature. ${ }^{25}$ Headspace gas was sampled and analyzed approximately every 2 weeks.

After 76 and 117 days, appropriate treatments were reamended as shown in Figure 1. The amendment was prepared identically to the

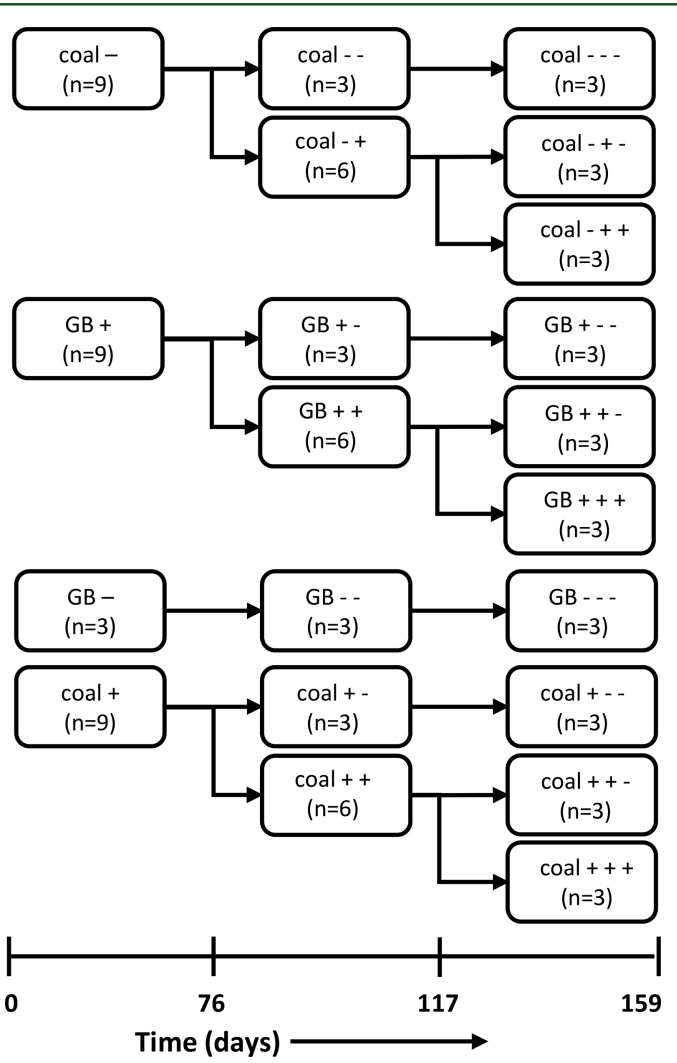

Figure 1. Experimental treatments (FG coal and glass bead (GB)) for each amendment time period. Amendment addition is indicated for each amendment time as "+" (addition of algal amendment in FG formation water) or "-” (addition of FG formation water only). The number of replicates is indicated as " $n=\#$ ".

initial microcosm set up and $1 \mathrm{~mL}$ of prepared amendment was added to each of the reamended treatments. Treatments not reamended with additional algae amendment received $1 \mathrm{~mL}$ of degassed FG formation water to account for volume changes and potential nutrient addition from the formation water added with the algal amendment.

2.4. Gas Analysis. Methane and carbon dioxide were monitored using an SRI Instruments (Torrance, CA, USA) Model 8610C gas chromatograph (GC) equipped with a thermal conductivity detector 

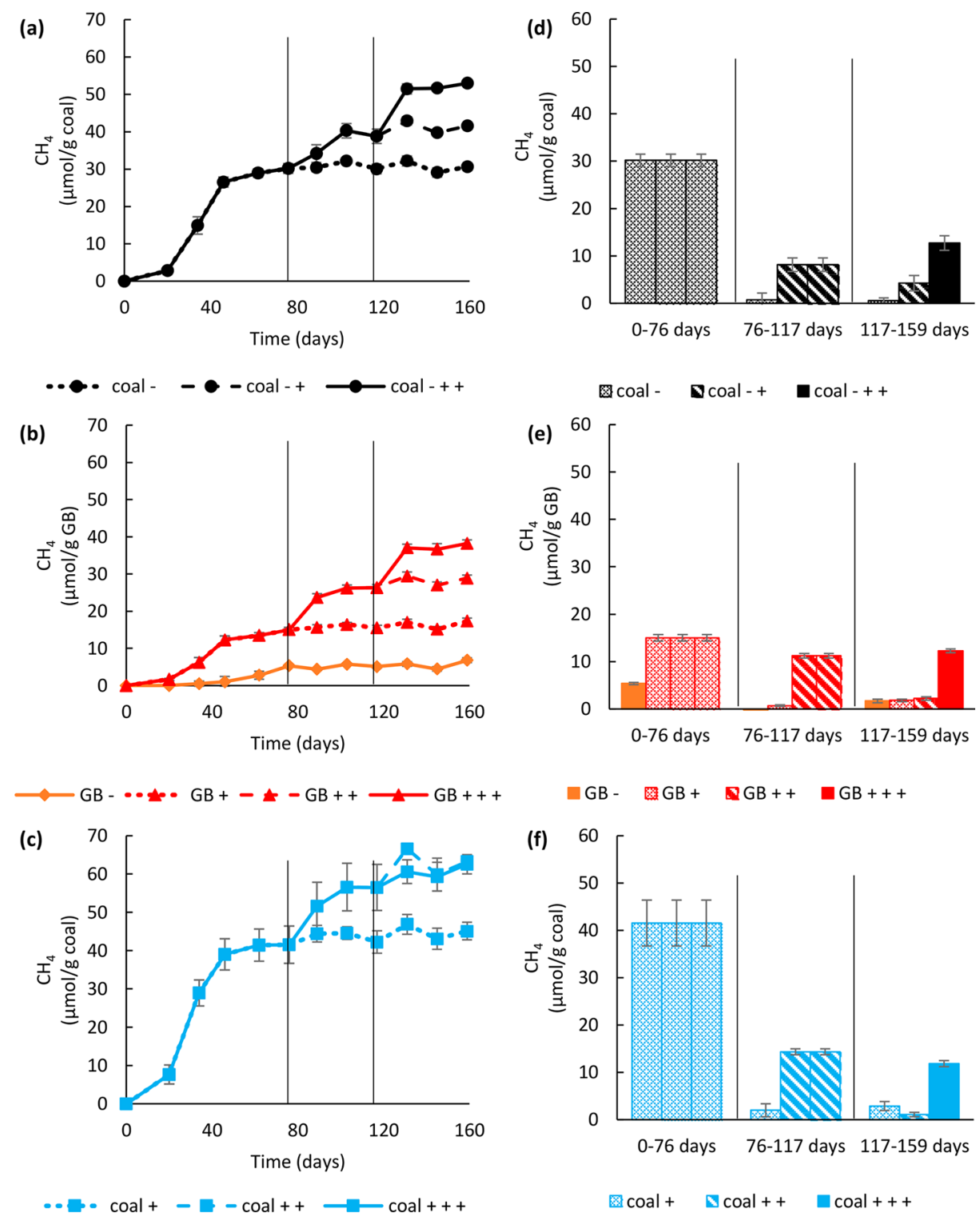

Figure 2. Methane production shown as a time series $(a-c)$ and as production per amendment period $(d-f)$ for initially unamended coal $(a, d)$, glass bead (b, e), and initially amended coal $(c, f)$ treatments. Error bars represent one standard deviation of 3-9 replicates (see Figure 1). Vertical lines indicate time of reamendment (where appropriate). Amendment addition for each of the three amendment periods are indicated with " + " for addition and "-" for no addition.

(TCD) interfaced with PeakSimple Chromatography software. A Supelco HayeSep-D packed stainless-steel column $(6$ feet $\times 1 / 8$ in. O.D.) was used with ultrahigh purity helium carrier gas for separation using the following conditions: manual injection, oven temperature 40 ${ }^{\circ} \mathrm{C}$, TCD temperature $150{ }^{\circ} \mathrm{C}$, and carrier gas pressure 8 psi. Gas $(1$ $\mathrm{mL}$ ) was collected from the microcosm headspace for GC injection. To prevent creating a negative pressure in the tubes, $1 \mathrm{~mL}$ of anoxic $5 \% \mathrm{CO}_{2} / 95 \% \mathrm{~N}_{2}$ gas was injected to replace the sample volume removed. After the initial 20-day incubation period, reactors were sampled approximately every 2 weeks for gas analysis for the duration of the 159-day study.

2.5. Carbon Analysis. Dissolved inorganic carbon (DIC) and nonpurgeable organic carbon (NPOC) were measured using a Formacs ${ }^{\mathrm{HT} / \mathrm{TN}}$ instrument (Skalar, Inc., Buford, GA, USA). Samples were centrifuged for $10 \mathrm{~min}$ at $4700 \mathrm{rpm}$ and $4{ }^{\circ} \mathrm{C}$ and filtered through $0.7 \mu \mathrm{m} \mathrm{GD} / \mathrm{X}$ filters. NPOC samples were acidified with $3 \mathrm{~N} \mathrm{HCl}$ to decrease the $\mathrm{pH}$ below 2 and purged with oxygen gas for $180 \mathrm{~s}$ prior to analysis. DIC and NPOC measurements were made every 4 weeks and on each reamendment day. Because these analyses required destructive sampling of reactors, only one reactor per treatment was sampled for each sampling date except at the end of the experiment on day 176 when DIC and NPOC measurements were taken by destructively sampling the three remaining samples of each treatment. Carbon, nitrogen, hydrogen, and sulfur analysis were performed on the dry algal biomass and lyophilized inoculum using a Thermo Scientific (Waltham, MA, USA) CE Elantech Flash 2000 CHNS-O Analyzer.

2.6. Statistical Analysis. A two-way ANOVA was fit to the amount of methane produced and the maximum methane production rate for each amendment period with a factor for treatment (coal or GB) and a factor for the amendment condition over time (i.e.,,++- , ++- , etc.). The ANOVA and Tukey tests of the interaction were performed using statistical software $\mathrm{R}^{27} \mathrm{~A} p$-value $<0.05$ determined statistical significance.

\section{RESULTS}

3.1. Methane Production. All treatments, regardless of solid substrate (coal, glass beads [GB]) or algal amendment regimen, produced methane during the 159-day study (Figure $2 \mathrm{a}-\mathrm{c})$, and the largest amount of methane was produced during 
Table 1. Rates of Methane Production ( \pm One Standard Deviation of 3-9 Replicates, Depending on the Period) Calculated for Each Treatment As an Average for Each Time Period between Gas Analyses ${ }^{a}$

\begin{tabular}{|c|c|c|c|}
\hline \multirow[b]{2}{*}{ treatment } & \multicolumn{3}{|c|}{ maximum methane production rate $\left(\mu \mathrm{mol} \mathrm{CH}_{4} /(\mathrm{g}\right.$ coal d $\left.)\right)$} \\
\hline & days $0-76$ & days $76-117$ & days $117-159$ \\
\hline coal --- & $0.97 \pm 0.21(n=9)$ & $0.12 \pm 0.12(n=3)$ & $0.15 \pm 0.05(n=3)$ \\
\hline coal -+- & & $0.44 \pm 0.08(n=6)$ & $0.40 \pm 0.12(n=3)$ \\
\hline coal -++ & & & $0.80 \pm 0.14(n=3)$ \\
\hline $\mathrm{GB}+--$ & $0.50 \pm 0.07(n=9)$ & $0.06 \pm 0.02(n=3)$ & $0.16 \pm 0.01(n=3)$ \\
\hline $\mathrm{GB}++-$ & & $0.66 \pm 0.03(n=6)$ & $0.20 \pm 0.03(n=3)$ \\
\hline $\mathrm{GB}+++$ & & & $0.79 \pm 0.01(n=3)$ \\
\hline $\mathrm{GB}---$ & $0.18 \pm 0.06(n=3)$ & $0.10 \pm 0.01(n=3)$ & $0.05 \pm 0.02(n=3)$ \\
\hline coal +-- & $1.52 \pm 0.13(n=9)$ & $0.32 \pm 0.02(n=3)$ & $0.33 \pm 0.06(n=3)$ \\
\hline coal ++- & & $0.73 \pm 0.10(n=6)$ & $0.31 \pm 0.06(n=3)$ \\
\hline coal +++ & & & $0.70 \pm 0.08(n=3)$ \\
\hline
\end{tabular}

${ }^{a}$ Maximum methane production rates for the 10 inoculated treatments for each amendment period are shown.

the first amendment period (days 0-76). During the second and third amendment periods (days 76-117 and 117-159, respectively), less methane was produced than during the initial amendment period, but more methane was always produced by treatments that were reamended compared to treatments that were not reamended (Figure 2d-f) $(p<0.05)$. Tukey comparison groupings are shown in Supplementary Table S1. After the initial amendment period, treatments that were not reamended produced little additional methane.

3.1.1. Initially Unamended Coal Treatments. During the first amendment period (days 0-76), the unamended coal treatments (coal - ) produced $30.2 \pm 1.3 \mu \mathrm{mol} \mathrm{CH} 4 / \mathrm{g}$ coal $(n$ =9) (Figure $2 \mathrm{~d})$. The methane production during the second amendment period (days 76-117) for unamended coal treatments $($ coal --$)$ was $0.7 \pm 1.5 \mu \mathrm{mol} \mathrm{CH}_{4} / \mathrm{g}$ coal $(n=$ 3 ). Initially unamended coal treatments that were amended on day $76($ coal -+$)$ produced an additional $8.2 \pm 1.4 \mu \mathrm{mol}$ $\mathrm{CH}_{4} / \mathrm{g}$ coal during the second amendment period $(n=6)$. During the third and final amendment period from days 117 to 159 , the unamended coal treatments (coal --- ) produced $0.6 \pm 0.6 \mu \mathrm{mol} \mathrm{CH} 4 / \mathrm{g}$ coal $(n=3)$; coal -+- treatments that were amended on day 76 but not reamended on day 117 produced an additional $4.3 \pm 1.6 \mu \mathrm{mol} \mathrm{CH}_{4} / \mathrm{g}$ coal $(n=3)$. Coal treatments amended on both days 76 and 117 (coal -++ ) produced $12.7 \pm 1.5 \mu \mathrm{mol} \mathrm{CH}_{4} / \mathrm{g}$ coal during amendment period $3(n=3)$.

3.1.2. Glass Bead Treatments. During the first amendment period (days 0 to 76 ), the unamended GB treatment (GB -) produced $5.4 \pm 0.2 \mu \mathrm{mol} \mathrm{CH}_{4} / \mathrm{g} \mathrm{GB}(n=3)$, whereas the initially amended $\mathrm{GB}$ treatments $(\mathrm{GB}+)$ produced $15.0 \pm 0.7$ $\mu \mathrm{mol} \mathrm{CH}_{4} / \mathrm{g} \mathrm{GB}(n=9)$ (Figure $2 \mathrm{e}$ ). On day 76 , six of the original $\mathrm{GB}$ + treatments were reamended. Between days 76 and 117, unamended $\mathrm{GB}$ treatments produced $-0.2 \pm 0.1$ $\mu \mathrm{mol} \mathrm{CH}_{4} / \mathrm{g} \mathrm{GB}(\mathrm{GB}--)$ and $0.7 \pm 0.2 \mu \mathrm{mol} \mathrm{CH}_{4} / \mathrm{g}$ GB $(\mathrm{GB}+-)(n=3$, both $)$. The six reamended GB treatments $(\mathrm{GB}++)$ produced $11.2 \pm 0.5 \mu \mathrm{mol} \mathrm{CH}_{4} / \mathrm{g}$ GB. During the third amendment period (days 117-159), GB amendments not reamended on day 117 produced $1.7 \pm 0.4 \mu \mathrm{mol} \mathrm{CH}_{4} / \mathrm{g} \mathrm{GB}$ (GB - - -), $1.8 \pm 0.3 \mu \mathrm{mol} \mathrm{CH} 4 / \mathrm{g} \mathrm{GB}(\mathrm{GB}+--)$, and 2.2 $\pm 0.4 \mu \mathrm{mol} \mathrm{CH} / \mathrm{g} \mathrm{GB}(\mathrm{GB}++-)(n=3$, each $) . \mathrm{GB}+++$ treatments were reamended on day 117 and produced an additional $12.3 \pm 0.4 \mu \mathrm{mol} \mathrm{CH}_{4} / \mathrm{g} \mathrm{GB}(n=3)$.

3.1.3. Initially Amended Coal Treatments. During the first 76-day amendment period, the initially amended coal treatments $\left(\right.$ coal + ) (Figure 2f) produced $41.5 \pm 4.9 \mu \mathrm{mol} \mathrm{CH}_{4} / \mathrm{g}$ coal $(n=9)$. Between days 76 and 117 , coal +- treatments $(n$
$=3$ ), which were not amended on day 76 , produced an additional $2.0 \pm 1.4 \mu \mathrm{mol} \mathrm{CH} / \mathrm{g}$ coal. Coal ++ treatments (reamended on day 76) produced $14.3 \pm 0.6 \mu \mathrm{mol} \mathrm{CH}_{4} / \mathrm{g}$ coal $(n=6)$ during the second amendment period. During the third amendment period (days 117-159), treatments not reamended on day 117 produced $2.9 \pm 0.9 \mu \mathrm{mol} \mathrm{CH}_{4} / \mathrm{g}$ coal $(\mathrm{coal}+--)$ and $1.1 \pm 0.5 \mu \mathrm{mol} \mathrm{CH}_{4} / \mathrm{g}(\mathrm{coal}++-)(n=3$, both $)$. Coal treatments $(\mathrm{coal}+++$ ), reamended on both day 76 and 117 , produced $11.8 \pm 0.6 \mu \mathrm{mol} \mathrm{CH}_{4} / \mathrm{g}$ coal during the third amendment period.

3.1.4. Comparisons of Amendment Regimens. During the first amendment period, the amended coal $($ coal +$)$ treatments produced significantly more methane than both the unamended coal $($ coal -$)$ treatments $(p<0.05)$ and the amended glass bead $(\mathrm{GB}+)$ treatments $(p<0.05), 1.4$ and 2.8 times, respectively. However, during the second amendment period, the coal ++ produced 1.7 times more methane than the coal $+(p<0.05)$ and 1.3 times the amount of methane produced by the $\mathrm{GB}++$ treatments $(p=0.574)$. During the last amendment period, the coal +++ produced a similar amount of methane as the coal $-++(p=1)$ and $\mathrm{GB}+++(p=1)$ treatments, 0.93 times and 0.96 times, respectively. When comparing the coal treatments only amended on day $0($ coal +--$)$ to coal treatments never amended (coal ---$)$, coal +-- produced significantly more (1.4 times) methane than coal - - - during amendment period $1(p<0.05)$. However, while coal +produced 2.9 times more methane during amendment period 2 than coal -- and coal +-- produced 3.0 times more than coal -- - during amendment period 3 , these small amounts of additional methane production were not statistically significantly different $(p=1)$ (Figure 2).

3.2. Methane Production Rates. Maximum rates of methane production for all treatments during each amendment period are shown in Table 1.

3.2.1. Initially Unamended Coal Treatments. The maximum rate of methane production observed during the first amendment period for unamended coal treatments (coal -) was $0.97 \pm 0.21 \mu \mathrm{mol} \mathrm{CH}_{4} /(\mathrm{g}$ coal $\mathrm{d})$ and occurred between days 34 and 46. During the second amendment period, both coal - - and coal -+ treatments had lower maximum methane production rates compared to the first amendment period $(p<0.05)$. Coal -- was not amended on day 76 and had a methane production rate of $0.12 \pm 0.12 \mu \mathrm{mol} \mathrm{CH}_{4} /(\mathrm{g}$ coal d). Coal -+ treatments were amended at the beginning of the second amendment period and had maximum methane production rates for this period of $0.44 \pm 0.08 \mu \mathrm{mol} \mathrm{CH}_{4} /(\mathrm{g}$ 
coal d). During the third amendment period (days 117-159), treatments not reamended on day 117 had maximum methane production rates of $0.15 \pm 0.05$ and $0.40 \pm 0.12 \mu \mathrm{mol} \mathrm{CH}_{4} /(\mathrm{g}$ coal d) for coal --- and coal -+- , respectively. Coal -++ treatments that were reamended on day 117 had a maximum methane production rate of $0.80 \pm 0.14 \mu \mathrm{mol} \mathrm{CH} /(\mathrm{g}$ coal d $)$ for the third amendment period. For all initially unamended coal treatments, the maximum methane production rates were significantly higher during the first amendment period ( $p<$ 0.05 ) except for coal -++ treatments which had a rate not statistically significantly different from the coal treatments $(p=$ $0.890)$. With amendment addition on days 76 and/or 117, maximum methane production rates were higher for coal -+ than coal $--(p<0.05)$ and higher for coal -++ than both coal --- and coal $-+-(p<0.05)$.

3.2.2. Glass Bead Treatments. The maximum rate for unamended GB treatments (GB -) between day 0 and 76 was $0.18 \pm 0.06 \mu \mathrm{mol} \mathrm{CH}_{4} /(\mathrm{g} \mathrm{GB} \mathrm{d})$ and occurred between days 62 and 76. The maximum rate for amended GB treatments occurred between days 34 and 46 and averaged $0.50 \pm 0.07$ $\mu \mathrm{mol} \mathrm{CH}_{4} /(\mathrm{g} \mathrm{GB} \mathrm{d})$ for all nine samples $(\mathrm{GB}+)$. For the GB treatments during the second amendment period, the maximum rates for GB treatments not reamended during the second amendment period were $0.10 \pm 0.01 \mu \mathrm{mol} \mathrm{CH} \mathrm{CH}_{4} /(\mathrm{g} \mathrm{GB}$ d) $(\mathrm{GB}--)$ and $0.06 \pm 0.02 \mu \mathrm{mol} \mathrm{CH}_{4} /(\mathrm{g} \mathrm{GB} \mathrm{d})(\mathrm{GB}+-)$. The maximum rate for $\mathrm{GB}$ treatments amended initially and reamended on day $76(\mathrm{~GB}++)$ was $0.66 \pm 0.03 \mu \mathrm{mol} \mathrm{CH}_{4} /(\mathrm{g}$ GB d), an increase from the $0.50 \pm 0.07 \mu \mathrm{mol} \mathrm{CH}_{4} /(\mathrm{g} \mathrm{GB} d)$ rate observed for initially amended GB treatments during the first period. Maximum methane production rates observed during the third amendment period for GB treatments not amended on day 117 were $0.05 \pm 0.02 \mu \mathrm{mol} \mathrm{CH}_{4} /(\mathrm{g} \mathrm{GB} \mathrm{d})$ for $\mathrm{GB}---, 0.16 \pm 0.01 \mu \mathrm{mol} \mathrm{CH}_{4} /(\mathrm{g} \mathrm{GB} \mathrm{d})$ for $\mathrm{GB}+--$, and $0.20 \pm 0.03 \mu \mathrm{mol} \mathrm{CH} \mathrm{CH}_{4} /(\mathrm{g} \mathrm{GB} \mathrm{d})$ for $\mathrm{GB}++-$. Only the $\mathrm{GB}+++$ treatments were reamended on day 117 and had a maximum rate of methane production of $0.79 \pm 0.01 \mu \mathrm{mol}$ $\mathrm{CH}_{4} /(\mathrm{g} \mathrm{GB} \mathrm{d})$, a possible increase over both of the previous amendment periods $(p>0.542)$.

3.2.3. Initially Amended Coal Treatments. During the first amendment period, the maximum rate for the amended coal treatments $($ coal +$)$ was significantly higher $(p<0.05)$ than for all other amended coal treatments at later times and occurred between days 20 and 34. This maximum rate averaged across all nine samples was $1.52 \pm 0.13 \mu \mathrm{mol} \mathrm{CH}_{4} /(\mathrm{g}$ coal $\mathrm{d})$ and was the highest methane production rate observed for all treatments over the duration of the study. During the second amendment period (days 76-117), treatments not amended on day 76 $($ coal +-$)$ had a maximum methane production rate of $0.32 \pm$ $0.02 \mu \mathrm{mol} \mathrm{CH}_{4} /(\mathrm{g}$ coal $\mathrm{d})$. The maximum rate for coal treatments amended initially and reamended on day 76 (coal + $+)$ was $0.73 \pm 0.10 \mu \mathrm{mol} \mathrm{CH}_{4} /(\mathrm{g}$ coal d $)(n=6)$. These rates were lower than the maximum rate observed for the coal + treatments during the first amendment period $(p<0.05)$ but higher than the rates for coal $+-(p<0.05)$. During the third amendment period (days 117-159), the maximum methane production rates for treatments not amended on day 117 were $0.33 \pm 0.06$ and $0.31 \pm 0.06 \mu \mathrm{mol} \mathrm{CH}_{4} /(\mathrm{g}$ coal d $)$ for coal +- and coal ++- . On day 117 , only the coal +++ treatments were reamended and had a maximum methane production rate of $0.70 \pm 0.08 \mu \mathrm{mol} \mathrm{CH}_{4} /(\mathrm{g}$ coal $\mathrm{d})$, similar to the rate observed for coal ++ treatments during the second amendment period $(p=1)$. Tukey comparison groupings for methane production rates are provided in Supplementary Table S2.
3.3. Inorganic carbon (IC) Production. Methanogenic biochemical pathways (eq 1-3) can produce or utilize carbon dioxide $\left(\mathrm{CO}_{2}\right)$. Hydrogenotrophic methanogenesis (eq 1) consumes $\mathrm{CO}_{2}$ while acetoclastic (eq 2) and methylotrophic (eq 3 ) methanogenesis produce $\mathrm{CO}_{2}$. In addition to methanogenesis, coal degradation reactions can produce or utilize $\mathrm{CO}_{2}{ }^{28,29}$

$$
\begin{aligned}
& \mathrm{CO}_{2}+4 \mathrm{H}_{2} \rightarrow \mathrm{CH}_{4}+2 \mathrm{H}_{2} \mathrm{O} \\
& \mathrm{CH}_{3} \mathrm{COOH} \rightarrow \mathrm{CH}_{4}+\mathrm{CO}_{2} \\
& 4 \mathrm{CH}_{3} \mathrm{OH} \rightarrow 3 \mathrm{CH}_{4}+\mathrm{CO}_{2}+2 \mathrm{H}_{2} \mathrm{O}
\end{aligned}
$$

$\mathrm{CO}_{2}$ is not the only form of inorganic carbon (IC) in these systems. Increased $\mathrm{CO}_{2}$ concentrations also result in increased bicarbonate $\left(\mathrm{HCO}_{3}{ }^{-}\right)$and carbonate $\left(\mathrm{CO}_{3}{ }^{2-}\right)$ concentrations and the ratio of these components of the carbonic acid system are $\mathrm{pH}$-dependent. Thus, dissolved inorganic carbon must be tracked in order to obtain a more complete carbon balance. Lastly, $\mathrm{CO}_{2}$ sorption to coal can occur.

3.3.1. Dissolved Inorganic Carbon (DIC) and $\mathrm{CO}_{2}$ Production. Dissolved inorganic carbon (DIC) was measured every 2-4 weeks during the 159-day study. The initial DIC for the prepared formation water used to set up all microcosms was $284 \pm 0.8 \mu \mathrm{mol} \mathrm{C} / \mathrm{g}$ coal or GB. Because destructive sampling was required for measurement, only one sample for each treatment was analyzed for each time point except for the final sampling on day 159 when triplicate samples were analyzed. Therefore, the variability between equivalent treatments was assessed for the final measurement only. When the DIC was measured on day 7 , the GB treatments exhibited a potentially small increase to $287 \mu \mathrm{mol} \mathrm{C} / \mathrm{g}$ GB while coal treatments displayed a decrease in DIC to $224 \mu \mathrm{mol} \mathrm{C} / \mathrm{g}$ coal for unamended coal treatments (coal -) and $229 \mu \mathrm{mol} \mathrm{C} / \mathrm{g}$ coal for amended coal treatments $($ coal +$)$ (Figure $3 \mathrm{a})$. These initial decreases in DIC observed in the coal treatments but not in GB treatments could be the result of $\mathrm{CO}_{2}$ sorption to the coal but not to GB. Apart from the initial decrease in DIC detected in all coal treatments, a general trend toward increasing DIC was observed for all treatments for the rest of the 159-day study. All GB treatments were associated with higher DIC concentrations than all coal treatments for the duration of the study. The observed increase in DIC may indicate a prevalence of acetoclastic and methylotrophic methanogenesis.

Headspace $\mathrm{CO}_{2}$ concentrations were measured for all treatments approximately every 2 weeks during the 159-day study (Figure $3 \mathrm{~b}$ ). The initial $\mathrm{CO}_{2}$ in the headspace of all treatments was $28.0 \pm 0.0 \mu \mathrm{mol} / \mathrm{g}$ coal or GB. By the first sampling on day 20 , unamended coal treatments (coal - ) had greater headspace $\mathrm{CO}_{2}$ concentrations $(45.5 \pm 3.6 \mu \mathrm{mol} / \mathrm{g}$ coal); amended $\mathrm{GB}$ treatments $(\mathrm{GB}+)$ had a $\mathrm{CO}_{2}$ concentration of $25.8 \pm 1.8 \mu \mathrm{mol} / \mathrm{g} \mathrm{GB}$; and amended coal treatments $(\mathrm{coal}+)$ had a headspace $\mathrm{CO}_{2}$ concentration of 49.7 $\pm 3.0 \mu \mathrm{mol} / \mathrm{g}$ coal. From day 20 to the end of the study, headspace $\mathrm{CO}_{2}$ concentrations changed little for all treatments, and in contrast to the DIC concentrations, headspace $\mathrm{CO}_{2}$ concentrations were higher for the coal treatments than for the GB treatments. One possible explanation for this observation is small differences in $\mathrm{pH}$ : the coal treatments had a slightly lower day $159 \mathrm{pH}(7.54-7.61)$ on day 159 while the GB treatments had a higher $\mathrm{pH}$ (7.90-8.10) (Supplementary Table S3).

3.3.2. Total System Inorganic Carbon. System IC was calculated by summing the headspace $\mathrm{CO}_{2}$ and dissolved 

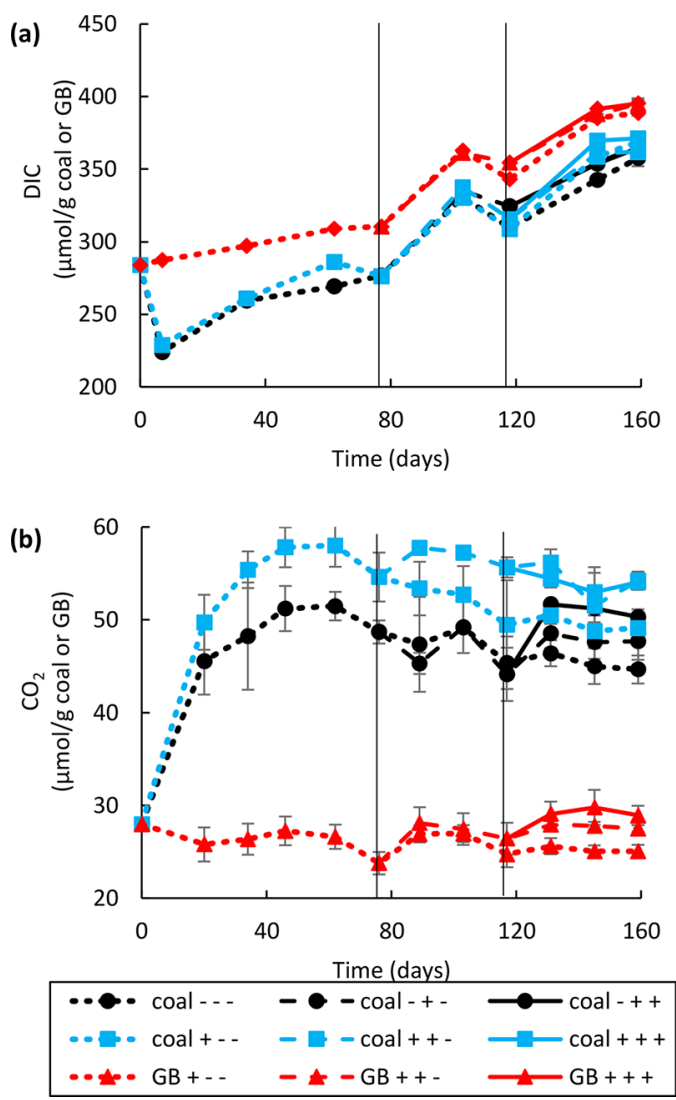

Figure 3. (a) Dissolved inorganic carbon (DIC) and (b) headspace $\mathrm{CO}_{2}$ concentrations in treatments. Reamendment (where appropriate) is indicated by vertical lines. DIC measurements are from single replicates, except on day $159 . \mathrm{CO}_{2}$ measurements with error bars indicating one standard deviation of 3-9 replicates (depending on the period, as per Figure 1)

inorganic carbon (DIC) concentrations. For these analyses, the sorption of IC to coal was assumed to have no effect on the measurable IC in the system. Produced amounts of IC for all systems are shown in Figure 3. DIC for unamended GB treatments $(\mathrm{GB}-)$ was not measured during the study because destructive sampling required more replicates than were initially set up. IC changes are reported here as "production", and a negative value for production would indicate a potential utilization of IC. However, because it was possible to only measure IC for one sample for each treatment for all time points except the final measurement on day 159, some of the negative "production" values may be attributed to naturally occurring differences between samples. All systems had a cumulative IC production for the 176-day study (Figure 4a-c).

During the first amendment period (days 0-76), unamended coal treatments (coal - ) produced $13.3 \mu \mathrm{mol} \mathrm{IC/g}$ coal. Amended GB treatments $(\mathrm{GB}+)$ produced $18.7 \mu \mathrm{mol} \mathrm{IC/g} \mathrm{GB}$ while amended coal treatments (coal + ) produced $38.6 \mu \mathrm{mol}$ IC/g coal. During the second amendment period, coal - treatments produced $29.9 \mu \mathrm{mol} \mathrm{IC} / \mathrm{g}$ coal while coal -+ treatments amended on day 76 produced $45.1 \mu \mathrm{mol} \mathrm{IC} / \mathrm{g}$ coal. $\mathrm{GB}+-$ treatments produced $37.6 \mu \mathrm{mol} \mathrm{IC} / \mathrm{g} \mathrm{GB}$, and GB ++ treatments produced $48.6 \mu \mathrm{mol} \mathrm{IC} / \mathrm{g}$ GB during amendment period 2. Initially amended coal treatments produced $14.0 \mu \mathrm{mol}$ IC/g coal for treatments not amended on day $76($ coal +-$)$ and $24.8 \mu \mathrm{mol} \mathrm{IC} / \mathrm{g}$ coal for amended treatments $($ coal ++ ).
During the third amendment period, coal treatments that were never amended (coal --- ) produced $1.7 \pm 3.2 \mu \mathrm{mol}$ $\mathrm{IC} / \mathrm{g}$ coal $(n=3)$. IC production by coal -+- treatments was $-1.2 \pm 3.9 \mu \mathrm{mol} \mathrm{IC} / \mathrm{g}$ coal. Coal -++ treatments amended on day 76 and day 117 produced $5.8 \pm 7.3 \mu \mathrm{mol} \mathrm{IC} / \mathrm{g}$ coal. Glass bead treatments, during the third amendment period, produced $-13.2 \pm 2.8 \mu \mathrm{mol} \mathrm{IC} / \mathrm{g}$ GB for GB +-- treatments, $-15.0 \pm$ $3.1 \mu \mathrm{mol} \mathrm{IC} / \mathrm{g} \mathrm{GB}$ for $\mathrm{GB}++-$ treatments, and $-10.9 \pm 5.2$ $\mu \mathrm{mol} \mathrm{IC} / \mathrm{g} \mathrm{GB}$ for $\mathrm{GB}+++$ treatments. IC produced during the third amendment period by initially amended coal treatments was $11.6 \pm 4.6 \mu \mathrm{mol} \mathrm{IC} / \mathrm{g}$ coal for coal +-treatments, $1.9 \pm 2.3 \mu \mathrm{mol} \mathrm{IC/g}$ coal for coal ++- , and 9.8 $\mu \mathrm{mol} \mathrm{IC} / \mathrm{g}$ coal for coal +++ .

3.4. Dissolved Nonpurgeable Organic Carbon. Nonpurgeable organic carbon (NPOC) was also measured every 24 weeks during the study. The initial NPOC for the prepared formation water used to set up microcosms was $57.9 \pm 0.8$ $\mu \mathrm{mol} \mathrm{C} / \mathrm{g}$ coal or GB. The initial increase in NPOC observed on day 7 (Figure 5a) to 187, 162, and $228 \mu \mathrm{mol} \mathrm{C/g}$ coal or GB for unamended coal (coal -), amended GB (GB +), and amended coal $($ coal +$)$, respectively, can potentially be attributed to NPOC carryover from the inoculum, dissolved organics in the algae amendment, and/or dissolution of coal organics after microcosm set up. After this initial increase, NPOC decreased to 35, 14, and $26 \mathrm{mg} \mathrm{C/L}$ for coal -, GB +, and coal + treatments, respectively, on day 35 . After this time, the NPOC decreased to less than $20 \mu \mathrm{mol} \mathrm{C} / \mathrm{g}$ coal or GB for all treatments and remained below $20 \mu \mathrm{mol} \mathrm{C} / \mathrm{g}$ coal or GB for all subsequent time points (Figure $5 \mathrm{~b}$ ).

3.5. Carbon Produced per Carbon Added. The total amount of carbon produced as methane and IC was compared to the total amount of carbon added as algae amendment $\left(\mathrm{C}_{\text {out }} / \mathrm{C}_{\text {in }}\right)$ during the 159 -day study (Figure 6$) . \mathrm{C}_{\text {out }} / \mathrm{C}_{\text {in }}$ ratios greater than 1 indicate that the amount of carbon converted to $\mathrm{CH}_{4}$ and IC exceeded the amount of carbon added with the algal amendment.

Comparing treatments of the same initial condition (coal -, $\mathrm{GB}+$, or coal + ), regardless of solid substrate, $\mathrm{C}_{\text {out }} / \mathrm{C}_{\text {in }}$ ratios decreased with each subsequent amendment (i.e., coal $+-->$ coal $++->$ coal +++ ). Unamended coal treatments (coal $--)$ were not amended during the study $\left(C_{\text {in }}=0\right)$ and therefore cannot be analyzed with this method. However, coal -+- treatments had a $\mathrm{C}_{\text {out }} / \mathrm{C}_{\text {in }}$ ratio of $2.7 \pm 0.1$ while coal ++ treatments had a lower ratio of $1.6 \pm 0.1$. For initially amended GB treatments, $\mathrm{GB}+--$ treatments had a $\mathrm{C}_{\text {out }} / \mathrm{C}_{\text {in }}$ ratio of $1.6 \pm 0.1$ whereas reamendment on day 76 resulted in a ratio of $1.1 \pm 0.0$ for $\mathrm{GB}++-$ treatments and reamendment on both day 76 and 117 resulted in a ratio of $0.9 \pm 0.1$ for $\mathrm{GB}++$ + treatments. The $\mathrm{C}_{\text {out }} / \mathrm{C}_{\text {in }}$ ratio for initially amended coal treatments was $3.0 \pm 0.1$ for coal +-- treatments, $1.7 \pm 0.1$ for coal ++- treatments, and $1.2 \pm 0.0$ for coal +++ treatments. The observation of decreasing $\mathrm{C}_{\text {out }} / \mathrm{C}_{\text {in }}$ ratios with sequential amendment addition suggests that reamendment results in a greater portion of produced methane being derived from the conversion of the amendment itself and less from other carbon sources including the conversion of coal to methane.

All amended coal and GB treatments except the $\mathrm{GB}+++$ treatments had a $\mathrm{C}_{\text {out }} / \mathrm{C}_{\text {in }}$ ratio greater than 1 . Therefore, all treatments except for the $\mathrm{GB}+++$ treatments produced more carbon as methane and IC than was added as algal amendment. Coal is indeed a significant carbon source for methane production in treatments containing coal. However, a $\mathrm{C}_{\text {out }} /$ 

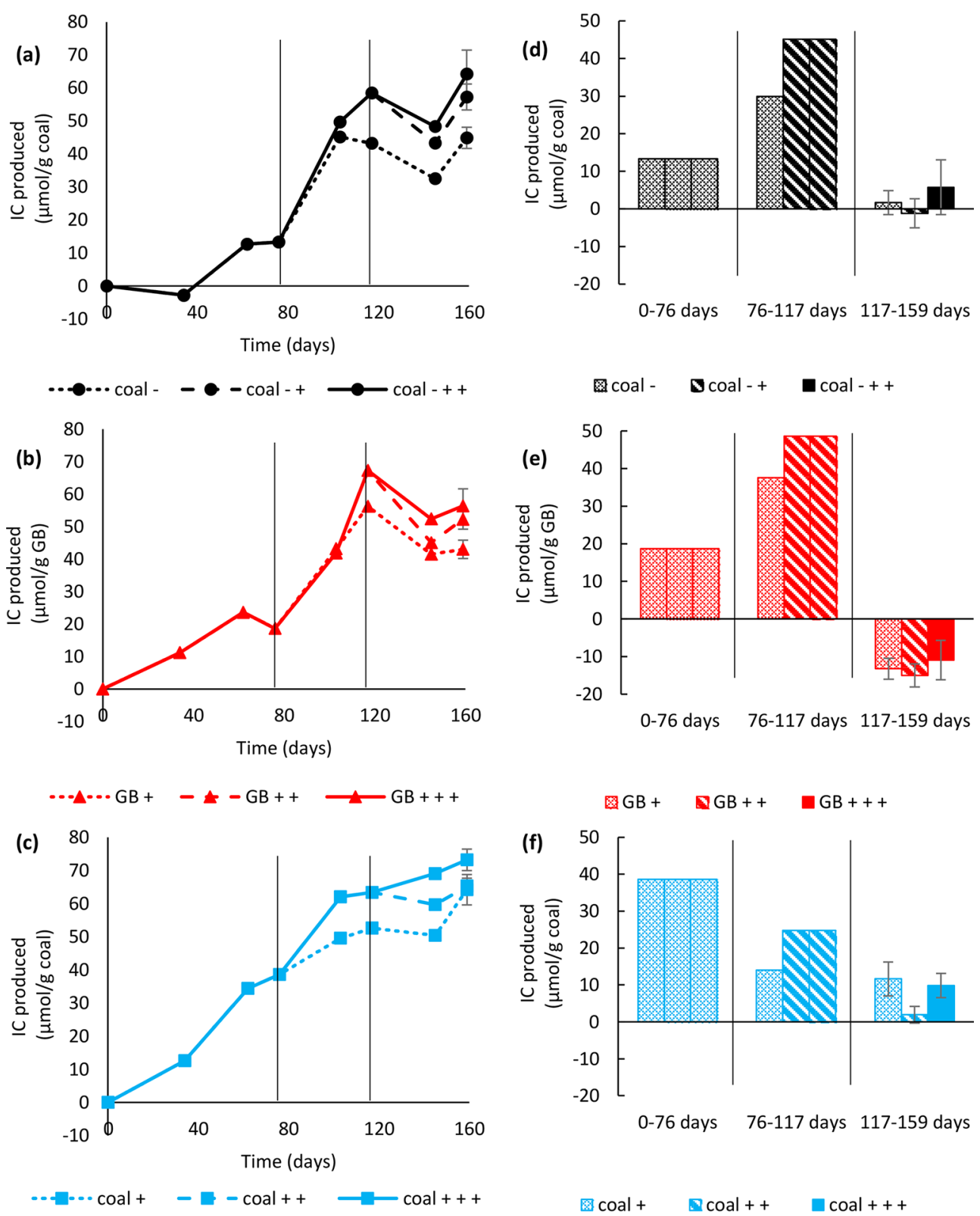

Figure 4. Inorganic carbon (IC) produced as time series $(a-c)$ and as production per amendment period (d-f) for initially unamended coal $(a, d)$, glass beads $(b, e)$, and initially amended coal ( $c, f)$ treatments. Error bars on day 159 represent one standard deviation for three replicates. Vertical lines designate amendment addition days.

$C_{\text {in }}$ ratio greater than 1 was also observed in the $\mathrm{GB}+--$ and $\mathrm{GB}++-$ treatments which did not have coal as an alternative carbon source (except for possible carry-over with the inoculum). Other sources of carbon in all systems potentially contributing to methane and IC production include initial dissolved organic carbon (DOC), dissolved inorganic carbon (DIC), carbon carried over with the inoculum, or biomass turnover of the initial microbial members.

\section{DISCUSSION}

During the initial amendment period, coal treatments produced more methane than the corresponding GB treatments for both amended and unamended treatments. These data corroborate the conclusion from previous studies that coal can be an important substrate for methane production. ${ }^{17,18}$ However, the amount of methane produced by amended coal treatments $($ coal +$)$ was 2.8 times the amount produced by the amended
GB treatments $(\mathrm{GB}+)$ during the first amendment period, but the amount of methane produced by reamended coal treatments $($ coal ++$)$ was only 1.3 times the amount produced by the reamended glass bead treatments $(\mathrm{GB}++)$ during the second amendment period. During the third amendment period, the coal +++ treatments produced approximately the same amount of methane as the $\mathrm{GB}+++$ treatments $(p=$ $1)$. Additionally, while the coal + treatments had a higher methane production rate in the first amendment period $(p<$ 0.05 ), during the second and third amendment periods the average methane production rate for amended coal treatments was not significantly different than for amended GB treatments $($ coal ++ vs $\mathrm{GB}++, \mathrm{GB}+++$ vs coal +++$)(p=1)$. These results indicate that the fraction of coal that can be easily converted into methane by the microbial community over the tested time period had been depleted or the microbial community had shifted away from coal utilization. These 

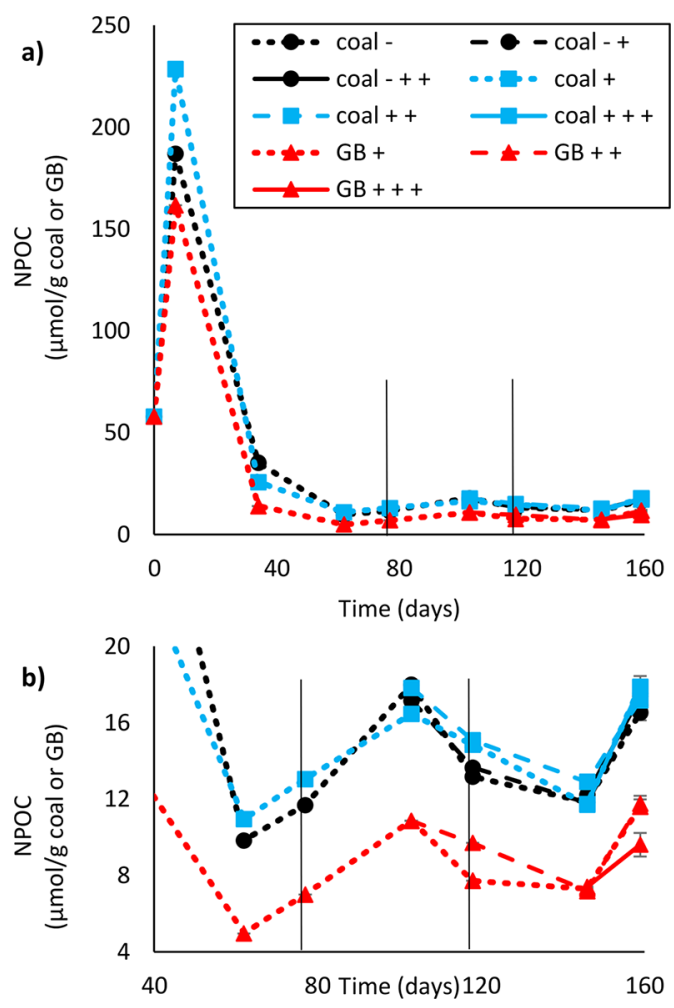

Figure 5. (a) Nonpurgeable organic carbon (NPOC) for treatments for all measured time points. (b) Days 40-159 to more clearly resolve the NPOC variations between treatments. Days of amendment addition, where appropriate, are indicated by vertical lines.

observations support the hypothesis that short-term reamendment of batch coal systems results in a resource utilization shift from the coal to the amendment itself and could be the result of a microbial community shift similar to that demonstrated previously with higher amendment concentrations. ${ }^{17}$

Previous research indicates coal-to-methane conversion in batch studies levels off after an initial production period. $^{10,11,14,17,30}$ This can likely be attributed to common limitations of batch systems such as substrate depletion or byproduct inhibition. ${ }^{31}$ In batch systems that contain a limited amount of coal, it is likely that the most bioavailable coal will be degraded first to produce $\mathrm{CH}_{4}, \mathrm{IC}$, and other byproducts. Once the easily degraded coal fraction has been utilized, the rate of methane production appears to decrease as the microbial community begins to degrade the more recalcitrant components of the coal matrix. In addition to the possible limitation of bioavailable coal substrate, the accumulation of degradation byproducts could become inhibitory for some microbial processes and result in the cessation of coal-dependent methanogenesis. ${ }^{16,24}$

Reamended treatments appear to produce similar amounts of methane, regardless of the solid substrate present (coal or glass beads). This observation suggests amendment-to-methane conversion is the primary source for methane production in these reamended systems. Amendment addition, after methane production has slowed, facilitates more methane production, and thus reamended systems, which are no longer substratelimited due to reamendment, do not appear to be inhibited by byproduct accumulation for amendment utilization during this study (i.e., methanogenesis is still possible in the presence of amendment).

All treatments were inoculated with $1 \mathrm{~mL}$ of the FG microbial consortium. Each milliliter of inoculum contained a measured $39.3 \pm 0.0 \mu \mathrm{mol} \mathrm{C}$ as biomass, DOC, DIC, and coal microparticles. It is unlikely that all of this carbon was converted to $\mathrm{CH}_{4}$ or IC, but it cannot be completely ruled out as a potential carbon source for methane or IC production. As shown in Figure 5, the measured NPOC, after an initial spike on day 7, decreased, and a comparison of NPOC measurements between day 0 and day 159 indicate a net loss of NPOC during the experiment: $41 \mu \mathrm{mol} \mathrm{C}$ for coal treatments and $47 \mu \mathrm{mol} \mathrm{C}$ for GB treatments. This net loss could be attributed to microbial processes resulting in methane or IC production. Because the NPOC measurement quantifies the total dissolved organics and does not identify specific organic compounds present, it is likely that some of these organics are potential methanogenic substrates or easily converted to known methanogenic substrates such as formate, acetate, or methylcompounds. ${ }^{29,30,32,33}$ The decrease in NPOC also could be due to consumption of organic carbon by microbes for biomass growth or sorption of organic carbon to coal which would not contribute to $\mathrm{CH}_{4}$ or IC production.

All estimates of methane and IC production made in the described studies assume the effects of sorption of $\mathrm{CH}_{4}$ and $\mathrm{CO}_{2}$ to coal are either negligible or affect all systems equally. However, it is possible that neglecting sorption of both $\mathrm{CH}_{4}$ and $\mathrm{CO}_{2}$ results in an underestimation of the amount of $\mathrm{CH}_{4}$ and/or IC present in the system due to the inability to measure the amounts of sorbed $\mathrm{CH}_{4}$ and $\mathrm{CO}_{2}$ in these systems without complete destructive sampling.

Coal sorption studies have shown preferential sorption of $\mathrm{CO}_{2}$ over $\mathrm{CH}_{4}$, and estimates for the relative amount of $\mathrm{CO}_{2}$ sorbed to coal compared to $\mathrm{CH}_{4}$ vary from $2: 1$ to $10: 1 .^{34}$ It is hypothesized that this preferential sorption can be attributed to several differences. The higher boiling point of $\mathrm{CO}_{2}$ and

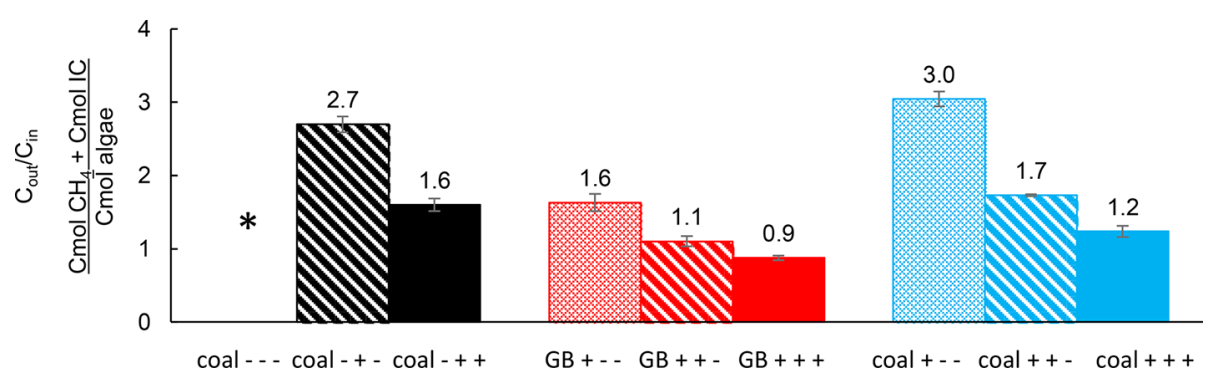

Figure 6. Ratio of produced methane and IC to algae added (normalized to the amount of carbon) for the entire 159-day study. Ratios greater than 1 indicate carbon production (as methane and IC) in excess of the carbon added as algae amendment. The initial amendment condition is labeled below each group. $(*)$ Coal --- treatments do not have data because algal amendment was not added. 
variations in physicochemical sorption processes result in increased adsorption energy of $\mathrm{CO}_{2}$. In addition, $\mathrm{CO}_{2}$ has a smaller molecular diameter than $\mathrm{CH}_{4}$ and thus can diffuse into smaller pores not accessible to $\mathrm{CH}_{4}{ }^{34}$ Many coal sorption studies have used dry coal. However, studies considering the effect of moisture on $\mathrm{CH}_{4}$ and $\mathrm{CO}_{2}$ sorption have shown that moisture reduces the sorption capacity of coal though $\mathrm{CO}_{2}$ is still preferentially sorbed. ${ }^{35,36}$

Adsorption and desorption studies were performed on dry Wyodak coal from the Powder River Basin. ${ }^{37}$ This subbituminous coal is from the Tongue River Member of the Fort Union Formation as is the Flowers-Goodale coal used in this study and is thus more relevant to the potential sorption effects in this study. The ratio of $\mathrm{CO}_{2}$ sorption relative to $\mathrm{CH}_{4}$ was estimated at 2.69 for Wyodak coal. Additionally, the adsorption and desorption isotherms indicated that even at atmospheric pressure, not all $\mathrm{CH}_{4}$ and $\mathrm{CO}_{2}$ can be desorbed from the Wyodak coal. ${ }^{37}$ The results suggests that the systems presented here, at near atmospheric pressure, are likely to have some amount of sorbed $\mathrm{CH}_{4}$ and $\mathrm{CO}_{2}$.

A decrease in DIC from day 0 to day 7 (Figure 3a) was observed in all coal treatments: -59.9 and $-55.0 \mu \mathrm{mol} \mathrm{C} / \mathrm{g}$ coal for unamended and amended coal treatments, respectively. Over the same time period, amended GB treatments had a possibly small increase in DIC of $+3.4 \mu \mathrm{mol}$ carbon. During the rest of the study, all samples had an overall trend of increasing DIC. While a few small decreases in DIC were observed later in the study, none were as large as the decrease observed in the first 7 days in the coal treatments. This initial decrease in DIC observed in coal treatments (but not in noncoal treatments) could be attributed to the sorption of $\mathrm{CO}_{2}$ to coal. After day 7 , the rate of IC production likely exceeded the sorption rate or produced methane sorbed to the coal to an extent that displaced some of the sorbed $\mathrm{CO}_{2}$ resulting in an increase in DIC. With an estimated $\mathrm{CO}_{2}$ to $\mathrm{CH}_{4}$ sorption ratio between $2: 1$ and $4: 1,{ }^{34,35}$ it is likely that $\mathrm{CH}_{4}$ sorption to coal is indeed a factor in these systems and suggests that $\mathrm{CH}_{4}$ production could be greater than measured.

\section{SUMMARY AND CONCLUSIONS}

The results presented here indicate that the amount and rate of biogenic $\mathrm{CH}_{4}$ production can be increased by the addition of algal amendments. However, in batch systems, after 60 to 80 days, $\mathrm{CH}_{4}$ production slows down or ceases completely, as demonstrated in our previous work. ${ }^{17}$ For potential long-term commercial applications, it is necessary to determine the potential benefits, challenges, and overall feasibility of reamending coal systems to achieve repeated enhancement of $\mathrm{CH}_{4}$ production and increase the total recoverable $\mathrm{CH}_{4}$. In addition, flow conditions at larger scales will most likely impact the halflife of the amendment as well as the ratio of amendment to overall coal. Future work is needed at meso- and field-scales to determine the impact of repeated amendment.

Reamendment, after $\mathrm{CH}_{4}$ production slowed, resulted in a temporary increase in $\mathrm{CH}_{4}$ production rates and amounts before $\mathrm{CH}_{4}$ production again declined. However, the rate and extent of methane production declined with each subsequent reamendment. After the third amendment, the additional $\mathrm{CH}_{4}$ production of amended coal treatments was equivalent to reamended glass bead systems (i.e., coal-dependent methanogenesis did not appear to be significant anymore). These results suggest a greater contribution of amendment-to-methane conversion in the tested batch coal systems with each subsequent reamendment. The apparent shift from coal-tomethane conversion to amendment-to-methane conversion after repeated amendments results in diminishing returns on investment and is similar to a previous assessment indicating that high amounts of amendment result in greater amendmentto-methane conversion instead of coal-dependent methanogenesis. ${ }^{17}$ For potential long-term commercial applications, it is necessary to determine the potential benefits, challenges, and feasibility of adding additional amendment to coal systems to prolong enhanced $\mathrm{CH}_{4}$ production and increase the total recoverable $\mathrm{CH}_{4}$ with existing infrastructure and wells.

\section{ASSOCIATED CONTENT}

\section{Supporting Information}

The Supporting Information is available free of charge on the ACS Publications website at DOI: 10.1021/acs.energyfuels.7b03426.

Additional methods information for gas content measurement and calculation. Tukey comparison groupings for amounts and rates of methane production as well as final $\mathrm{pH}$ measurements (PDF)

\section{AUTHOR INFORMATION}

\section{Corresponding Authors}

*Tel.: 1-406-270-3192. Fax:1-406-994-6098. E-mail: katherine. jn.davis@gmail.com (K.J.D.).

*Tel: 1-406-994-1840. Fax: 1-406-994-6098. Email: robin_g@ montana.edu (R.G.).

ORCID ${ }^{-0}$

Katherine J. Davis: 0000-0002-0562-7035

Robin Gerlach: 0000-0002-7669-3072

\section{Notes}

Any use of trade, firm, or product names is for descriptive purposes only and does not imply endorsement by the U.S. Government.

The authors declare no competing financial interest.

\section{ACKNOWLEDGMENTS}

The authors would like to thank Albert E. Parker for his guidance with the statistical analyses and acknowledge the U.S. Geological Survey Energy Resources Program which provided access to the field site where the samples were collected. Funding for this project was provided by the Department of Energy (DE-FE0024068). Partial financial support was provided by the Montana Research and Economic Development Initiative Contract no. 51040-MUSRI2015-05, NSF CHE-1230632, and NSF EAR-1322795.

\section{REFERENCES}

(1) Colosimo, F.; Thomas, R.; Lloyd, J. R.; Taylor, K. G.; Boothman, C.; Smith, A. D.; Lord, R.; Kalin, R. M. Biogenic methane in shale gas and coal bed methane: A review of current knowledge and gaps. Int. J. Coal Geol. 2016, 165, 106-120.

(2) Moore, T. A. Coalbed methane: A review. Int. J. Coal Geol. 2012, 101, 36-81.

(3) Park, S. Y.; Liang, Y. Biogenic methane production from coal: A review on recent research and development on microbially enhanced coalbed methane (MECBM). Fuel 2016, 166, 258-267.

(4) Ritter, D.; Vinson, D.; Barnhart, E.; Akob, D. M.; Fields, M. W.; Cunningham, A. B.; Orem, W.; McIntosh, J. C. Enhanced microbial coalbed methane generation: A review of research, commercial activity, and remaining challenges. Int. J. Coal Geol. 2015, 146, 28-41. 
(5) Flores, R. M.; Rice, C. A.; Stricker, G. D.; Warden, A.; Ellis, M. S. Methanogenic pathways of coal-bed gas in the Powder River Basin, United States: The geologic factor. Int. J. Coal Geol. 2008, 76 (1-2), $52-75$.

(6) Golding, S. D.; Boreham, C. J.; Esterle, J. S. Stable isotope geochemistry of coal bed and shale gas and related production waters: A review. Int. J. Coal Geol. 2013, 120, 24-40.

(7) Strąpoć, D.; Mastalerz, M.; Dawson, K.; Macalady, J.; Callaghan, A. V.; Wawrik, B.; Turich, C.; Ashby, M. Biogeochemistry of Microbial Coal-Bed Methane. Annu. Rev. Earth Planet. Sci. 2011, 39 (1), 617656.

(8) Meredith, E.; Wheaton, J.; Kuzara, S. Coalbed Methane Basics: Ten Years of Lessons from the Powder River Basin; Information Pamphlet 6; Montana Bureau of Mines and Geology, MT, 2012.

(9) Rice, C. A.; Nuccio, V. Water Produced with Coal-Bed Methane, FS 156-00; U.S. Geological Survey Fact Sheet, 2000.

(10) Green, M. S.; Flanegan, K. C.; Gilcrease, P. C. Characterization of a methanogenic consortium enriched from a coalbed methane well in the Powder River Basin, U.S.A. Int. J. Coal Geol. 2008, 76 (1-2), $34-45$.

(11) Ulrich, G.; Bower, S. Active methanogenesis and acetate utilization in Powder River Basin coals, United States. Int. J. Coal Geol. 2008, 76 (1-2), 25-33.

(12) Gallagher, L. K.; Glossner, A. W.; Landkamer, L. L.; Figueroa, L. A.; Mandernack, K. W.; Munakata-Marr, J. The effect of coal oxidation on methane production and microbial community structure in Powder River Basin coal. Int. J. Coal Geol. 2013, 115, 71-78.

(13) Huang, Z.; Urynowicz, M. A.; Colberg, P. J. S. Stimulation of biogenic methane generation in coal samples following chemical treatment with potassium permanganate. Fuel 2013, 111, 813-819.

(14) Jones, E. J. P.; Harris, S. H.; Barnhart, E. P.; Orem, W. H.; Clark, A. C.; Corum, M. D.; Kirshtein, J. D.; Varonka, M. S.; Voytek, M. A. The effect of coal bed dewatering and partial oxidation on biogenic methane potential. Int. J. Coal Geol. 2013, 115, 54-63.

(15) Huang, Z.; Urynowicz, M. A.; Colberg, P. J. S. Bioassay of chemically treated subbituminous coal derivatives using Pseudomonas putida F1. Int. J. Coal Geol. 2013, 115, 97-105.

(16) Zhang, J.; Park, S. Y.; Liang, Y.; Harpalani, S. Finding costeffective nutrient solutions and evaluating environmental conditions for biogasifying bituminous coal to methane ex situ. Appl. Energy 2016, $165,559-568$.

(17) Davis, K. J.; Lu, S.; Barnhart, E. P.; Parker, A. E.; Fields, M. W.; Gerlach, R. Type and amount of organic amendments affect enhanced biogenic methane production from coal and microbial community structure. Fuel 2018, 211, 600-608.

(18) Barnhart, E. P.; Davis, K. J.; Varonka, M.; Orem, W.; Cunningham, A. B.; Ramsay, B. D.; Fields, M. W. Enhanced coaldependent methanogenesis coupled with algal biofuels: Potential water recycle and carbon capture. Int. J. Coal Geol. 2017, 171, 69-75.

(19) Solaiman, D. K. Y.; Ashby, R. D.; Zerkowski, J. A.; Foglia, T. A. Simplified soy molasses-based medium for reduced-cost production of sophorolipids by Candida bombicola. Biotechnol. Lett. 2007, 29 (9), 1341-1347.

(20) Vilcáez, J. Stimulating effect of protein-rich matter on the biogenic conversion of $\mathrm{CO} 2$ to CH4. J. CO2 Util. 2015, 10, 60-66.

(21) Hodgskiss, L. H.; Nagy, J.; Barnhart, E. P.; Cunningham, A. B.; Fields, M. W. Cultivation of a native alga for biomass and biofuel accumulation in coal bed methane production water. Algal Res. 2016, 19, 63-68.

(22) Priyadarshani, I.; Rath, B. Commercial and industrial applications of micro algae-A review. J. Algal Biomass Util. 2012, 3 (4), 89-100.

(23) Guo, H.; Zhang, J.; Han, Q.; Huang, Z.; Urynowicz, M. A.; Wang, F. Important Role of Fungi in the Production of Secondary Biogenic Coalbed Methane in China's Southern Qinshui Basin. Energy Fuels 2017, 31 (7), 7197-7207.

(24) Zhang, J.; Liang, Y. Evaluating approaches for sustaining methane production from coal through biogasification. Fuel 2017, 202, 233-240.
(25) Barnhart, E. P.; Weeks, E. P.; Jones, E. J. P.; Ritter, D. J.; McIntosh, J. C.; Clark, A. C.; Ruppert, L. F.; Cunningham, A. B.; Vinson, D. S.; Orem, W.; et al. Hydrogeochemistry and coal-associated bacterial populations from a methanogenic coal bed. Int. J. Coal Geol. 2016, 162, 14-26.

(26) Barnhart, E. P.; De León, K. B.; Ramsay, B. D.; Cunningham, A. B.; Fields, M. W. Investigation of coal-associated bacterial and archaeal populations from a diffusive microbial sampler (DMS). Int. J. Coal Geol. 2013, 115, 64-70.

(27) R Core Team. R: A Language and environment for statistical computing; R Foundation for Statistical Computing: Vienna, Austria, 2017.

(28) Schink, B. Syntrophic Associations in Methanogenic Degradation. In Molecular Basis of Symbiosis; Overmann, P. D. J., Ed.; Progress in Molecular and Subcellular Biology; Springer: Berlin Heidelberg, 2005; pp 1-19.

(29) McInerney, M. J.; Struchtemeyer, C. G.; Sieber, J.; Mouttaki, H.; Stams, A. J. M.; Schink, B.; Rohlin, L.; Gunsalus, R. P. Physiology, Ecology, Phylogeny, and Genomics of Microorganisms Capable of Syntrophic Metabolism. Ann. N. Y. Acad. Sci. 2008, 1125 (1), 58-72.

(30) Harris, S. H.; Smith, R. L.; Barker, C. E. Microbial and chemical factors influencing methane production in laboratory incubations of low-rank subsurface coals. Int. J. Coal Geol. 2008, 76 (1-2), 46-51.

(31) Doran, P. M. Bioprocess Engineering Principles, 1st ed.; Academic Press Limited: London, UK, 1995.

(32) Wawrik, B.; Mendivelso, M.; Parisi, V. A.; Suflita, J. M.; Davidova, I. A.; Marks, C. R.; Nostrand, J. D.; Liang, Y.; Zhou, J.; Huizinga, B. J.; et al. Field and laboratory studies on the bioconversion of coal to methane in the San Juan Basin. FEMS Microbiol. Ecol. 2012, 81 (1), 26-42.

(33) Singh, D. N.; Kumar, A.; Sarbhai, M. P.; Tripathi, A. K. Cultivation-independent analysis of archaeal and bacterial communities of the formation water in an Indian coal bed to enhance biotransformation of coal into methane. Appl. Microbiol. Biotechnol. 2012, 93 (3), 1337-1350.

(34) Harpalani, S.; Prusty, B. K.; Dutta, P. Methane/CO2 Sorption Modeling for Coalbed Methane Production and $\mathrm{CO} 2$ Sequestration. Energy Fuels 2006, 20 (4), 1591-1599.

(35) Busch, A.; Gensterblum, Y. CBM and CO2-ECBM related sorption processes in coal: A review. Int. J. Coal Geol. 2011, 87 (2), 49-71.

(36) Merkel, A.; Gensterblum, Y.; Krooss, B. M.; Amann, A. Competitive sorption of $\mathrm{CH} 4, \mathrm{CO} 2$ and $\mathrm{H} 2 \mathrm{O}$ on natural coals of different rank. Int. J. Coal Geol. 2015, 150-151, 181-192.

(37) Busch, A.; Gensterblum, Y.; Krooss, B. M. Methane and CO2 sorption and desorption measurements on dry Argonne premium coals: pure components and mixtures. Int. J. Coal Geol. 2003, 55 (24), 205-224. 